\title{
Cellular proliferation in mouse and human pancreatic islets is regulated by serpin B13 inhibition and downstream targeting of E-cadherin by cathepsin L
}

\author{
Chi-Wen Lo ${ }^{1} \cdot$ Yury Kryvalap ${ }^{2} \cdot$ Tzong-jen Sheu $^{3} \cdot$ Ching-Ho Chang $^{4} \cdot$ Jan Czyzyk $^{2}$
}

Received: 4 December 2018 / Accepted: 22 January 2019 /Published online: 1 March 2019

(C) Springer-Verlag GmbH Germany, part of Springer Nature 2019

\begin{abstract}
Aims/hypothesis We previously reported that exposure to antibodies neutralising serpin B13, a protease inhibitor expressed in exocrine pancreatic ducts, promotes beta cell proliferation, underscoring the importance of a functional relationship between exocrine and endocrine pancreas. The aim of the present study was to identify the molecular events that link inhibition of serpin B13 to islet cell proliferation.

Methods We used an in vitro culture system consisting of isolated pancreatic islets, an extract of pancreatic ductal epithelium and a monoclonal antibody $(\mathrm{mAb})$ to serpin B13 or IgG isotype control. In vivo studies involved treatment of mice with these mAbs. Results The catalytic activity of cathepsin L (CatL), a cysteine protease target of serpin B13, was augmented in the pancreas of mice injected with serpin B13 mAb. Furthermore, the addition of serpin B13 mAb to the islets, together with the pancreatic ductal epithelium lysate, caused CatL-dependent cleavage of E-cadherin and concomitant upregulation of REG genes, ultimately leading to beta cell proliferation. Direct blockade of E-cadherin with $\mathrm{mAb}$ also markedly enhanced REG gene induction, while chemical inhibition of $\beta$-catenin, a binding target of E-cadherin, prevented the serpin B13 mAb-induced upregulation of REG genes.

Conclusions/interpretation Our work implicates the CatL-E-cadherin-REG pathway in the regulation of islet cell proliferation in response to signals generated in exocrine pancreatic tissue and demonstrates that protease activity may promote adaptive changes in the islets.

Data availability Microarray data that support the findings of this study have been deposited in Gene Expression Omnibus (GEO) with the accession no. GSE125151.
\end{abstract}

Keywords Beta cell proliferation $\cdot$ Pancreatic islets $\cdot$ Proteases $\cdot$ Serpins

Electronic supplementary material The online version of this article (https://doi.org/10.1007/s00125-019-4834-0) contains peer-reviewed but unedited supplementary material, which is available to authorised users.

Jan Czyzyk

jczyzyk@umn.edu

1 Department of Pathology and Laboratory Medicine, University of Rochester, Rochester, NY, USA

2 Department of Laboratory Medicine and Pathology, University of Minnesota, 420 Washington Ave SE, Minneapolis, MN 55455, USA

3 The Center for Musculoskeletal Research, University of Rochester, Rochester, NY, USA

4 Department of Biology, University of Rochester, Rochester, NY, USA
Abbreviations
CatL Cathepsin L
DBA Dolichos biflorus agglutinin
5-Edu 5-Ethyl-2'-deoxyuridine
$\mathrm{mAb}$ Monoclonal antibody

\section{Introduction}

The pancreas is composed of two dominant tissue types: small clusters of endocrine cells called the islets of Langerhans and exocrine cells in the surrounding stroma. These tissue types differ fundamentally in terms of anatomical organisation and basic function and are consequently independent with respect 


\section{Research in context}

\section{What is already known about this subject?}

- Serpins are protease inhibitors that are critical for the survival of multicellular organisms

- Antibodies have been shown to block the inhibitory activity of serpins thereby allowing preservation of the function of their target proteases

- Our laboratory has identified a novel autoantibody against serpin B13 (a protease inhibitor of cathepsin L) that enhances proliferation of beta cells in pancreatic islets

\section{What is the key question?}

- What is the molecular mechanism by which cathepsin $L$ promotes beta cell proliferation?

\section{What are the new findings?}

- $\quad$ REG proteins are responsible for beta cell proliferation following inhibition of serpin B13

- Cathepsin L (here induced by treatment with serpin B13 mAb) is necessary for REG gene expression in pancreatic islets

- E-cadherin downregulation by cathepsin L promotes REG expression in the islets

\section{How might this impact on clinical practice in the foreseeable future?}

- Passive immunisation with an inhibitory antibody to serpin B13 may offer a novel and practical approach to help prevent pancreatic beta cell loss

to their biological roles and pathological conditions. However, detailed examination of the pancreas shows that many islets are positioned in close proximity to the exocrine ducts or contain small exocrine conduits. This raises the possibility that the endocrine and exocrine pancreas do not operate in isolation but rather remain in a close functional relationship which influences the islets. Our interest in potential functional crosstalk between the exocrine and endocrine pancreas stems from our discovery of a novel autoantibody, directed against serpin $\mathrm{B} 13$, that is expressed in the ductal epithelium of the exocrine pancreas [1]. Serpin B13 is a member of the clade B family of proteins, which consist of several potent cysteine and serine protease inhibitors implicated in regulating proliferation, angiogenesis and tumorigenesis [2-4].

Since others have shown that targeting the exocrine pancreatic tree with pancreatic ductal ligation stimulates beta cell proliferation [5], we questioned whether challenging the ductal compartment in the pancreas with alternative approaches, including anti-serpin B13 monoclonal antibody (mAb), could also result in islet adaptive changes. Indeed, we found that anti-serpin B13 activity enhanced proliferation of insulinproducing cells in the islets in vivo, increased the number of pancreatic islets, increased beta cell mass and protected animals against severe diabetes in NOD and streptozotocininduced mouse models [6].

A family of C-type lectin molecules called REG has been heavily implicated in regenerating pancreatic islets. REG1 was found to regenerate rat islets after pancreatectomy and the expression of Regl was correlated with increased islet size and decreased urinary glucose, suggesting a potential role for this gene in normal replication, growth, and maturation of islet beta cells [7]. Reg2 also has similar effects on islet biology as its expression is evident in hyperplastic islets and correlated with better outcomes in diabetic NOD mice [8]. Among type III REGs, REG3D, also known as islet neogenesis associated protein (INGAP), has been the most frequently studied for its role in increasing beta cell mass, reversing diabetes and stimulating beta cell neogenesis from ductal cells $[9,10]$. Finally, REG3G, a mouse homologue of human REG3A, has been implicated in keratinocyte proliferation through activation of phosphatidylinositol 3 kinase and the kinase AKT [11].

The current study was undertaken in an attempt to examine whether the molecular pathway exists to link the anti-serpin immunological response to beta cell proliferation. We focused on cathepsin L (CatL) as this protease is a target of serpin B13. In addition, we examined REG proteins because our microarray experiments revealed these molecules to be upregulated following exposure to anti-serpin B13 antibodies.

\section{Methods}

Animals BALB/c and CatL-deficient NOD (NOD.129P2(B6)$\mathrm{Ctsl}^{\text {tml I }}{ }^{\mathrm{Btr}} / \mathrm{RclJ}$ ) mice of both sexes were obtained from the Jackson Laboratory (Bar Harbor, ME, USA). The CatLdeficient mice were backcrossed on BALB/c background for at least 20 generations. Mice (five per cage) were housed in a temperature- and light-controlled room (12 h days-nights) 
using 1/8" Performance Bedding (BioFresh, Ferndale, WA, USA) and 5010 chow (LabDiet, St Louis, MO, USA). The 'Guide for the care and use of laboratory animals', eighth edition (2011) was followed. The University Committee on Animal Resources at the University of Rochester approved all mouse experiments.

Antibodies The mouse anti-serpin B13 mAb (clone B29) recognising mouse and human protein, was described previously $[1,12]$. TIB92 (control IgG) was from the ATCC (Manassas, VA, USA). For in vivo experiments examining intra-islet REG or E-cadherin expression, mice were intraperitoneally injected four times with $25 \mu \mathrm{g}$ B29 or TIB92 $\mathrm{mAb}$. In experiments examining CatL activity, mice were injected with a single dose of $250 \mu \mathrm{g} \mathrm{mAb}$. Mice were injected with antibodies in their home cages during afternoon hours. To inhibit E-cadherin in vitro, the mAb, clone DECMA-1 (Invitrogen, Carlsbad, CA, USA), was used in the islet cultures $(2 \mu \mathrm{g} / \mathrm{ml})$. Immunoblots were stained with antibodies recognising $\alpha$-tubulin (diluted 1:1000; Cell Signaling Technology, Danvers, MA, USA), lamin B (1:1000; Santa Cruz Biotechnology, Dallas, TX, USA), E-cadherin ( $1 \mu \mathrm{g} / \mathrm{ml}$; Invitrogen), REG1 (1:1000; Abcam, Cambridge, UK), $\beta$-catenin $(1: 1000$, Abcam) and V5 epitope tag (1:1000; Biolegend, San Diego, CA, USA). Horseradish peroxidase-conjugated anti-rabbit, antimouse or anti-rat polyclonal antibodies (1:20,000; SigmaAldrich, St Louis, MO, USA) were used as secondary reagents. To neutralise REG proteins in vitro, polyclonal antibodies to REG1, REG2 and REG3D (R\&D Systems, Minneapolis, MN, USA) or IgG isotype control (Innovative Research, Novi, MI, USA) were added to the islet cultures $(4 \mu \mathrm{g} / \mathrm{ml}$ each). Antibodies were stored and diluted in phosphate buffered saline (PBS). B29 was validated by western blotting (ESM Fig. 1).

Other reagents E64 protease inhibitor (N-[transepoxysuccinyl]-L-leucine 4-guanidinobutylamide), CatL inhibitor II (Z-FY-CHO) and CATHEPSIN B inhibitor II (AcLVK-CHO) were from Calbiochem (Millipore, Billerica, MA, USA). The $\beta$-CATENIN/Tcf inhibitor FH535 (N-[2-methyl4-nitrophenyl]-2,5-dichlorobenzenesulfonamide) was from Santa Cruz Biotechnology. Ethylene glycol-bis( $\beta$ aminoethyl ether)- $N, N, N^{\prime}, N^{\prime}$-tetraacetic acid (EGTA) was used at $2 \mu \mathrm{mol} / 1$. 5-Ethyl-2'-deoxyuridine (5-Edu) was from Carbosynth (San Diego, CA, USA).

Cell culture Capan-2 and 293 cells (both from ATCC) and mouse insulinoma MIN6 cells (AddexBio Technologies, San Diego, CA, USA), were cultured in DMEM containing 10 $15 \% \mathrm{FBS}, 2 \mathrm{mmol} / \mathrm{l} \mathrm{L}$-glutamine, and $100 \mathrm{U} / \mathrm{ml}$ penicillin and streptomycin. PCR method was employed to verify mycoplasma-free status of cell lines used in this study.
Isolation and in vitro culture of pancreatic islets Mouse islets were isolated using the collagenase P/DNase I digestion method followed by handpicking under a stereomicroscope. Islet size was determined using a MR400 microscopic calibration slide (AmScope, Irvine, CA, USA). The islets were cultured in RPMI-1640 medium supplemented with 10\% FBS and antibiotics. Human islets from six donors were obtained from the Integrated Islet Distribution Program following Institutional Review Board approval. The age of the donors was $36.86 \pm$ 15.55 years and their BMI was $24.38 \pm 2.47 \mathrm{~kg} / \mathrm{m}^{2}$. None of the donors had a history of diabetes and their $\mathrm{HbA}_{1 \mathrm{c}}$ was $35.33 \pm 1.7 \mathrm{mmol} / \mathrm{mol}(5.3 \% \pm 0.14 \%)$.

Isolation of pancreatic ductal cells Ductal cells were isolated according to the protocol developed previously [13]. The pancreases from 8-week-old mice were digested with collagenase IV (Sigma-Aldrich). Next, the pancreatic cell suspensions were incubated with FITC-labelled Dolichos biflorus agglutinin (DBA) lectin (1:400; Vector Labs, Burlingame, CA, USA) followed by MicroBeads conjugated with antiFITC (1:10; Miltenyi Biotec, Bergisch Gladbach, Germany). The DBA lectin-positive cells were separated on MS columns (Miltenyi Biotec) using a magnetic field.

Ductal cell lysate preparation and islet treatment Mouse primary ductal cells $\left(8 \times 10^{5}\right)$ or human pancreatic carcinoma Capan-2 cells $\left(2 \times 10^{6}\right)$ were homogenised in $1 \mathrm{ml}$ PBS containing control $\mathrm{IgG}$ or anti-serpin B13 mAb (4 $\mu \mathrm{g} / \mathrm{ml})$ using a bullet blender with stainless-steel beads measuring $0.9-2 \mathrm{~mm}$ in diameter. Islets (100 per sample) were added to $10 \% \mathrm{FBS} / \mathrm{RPMI}$ culture medium diluted 1:1 with ductal cell lysate for different periods. The islets were then processed for RNA isolation or FACS analysis. For stimulation with CatL, the islets were incubated with different concentrations of recombinant protein (Sino Biological, North Wales, PA, USA) in RPMI at $\mathrm{pH} 6.0$ for $4 \mathrm{~h}$. The islets were then washed in PBS and cultured in 10\% FBS/RPMI medium for 2 days before harvesting. In some experiments, proliferation of insulin-producing cells was assessed following incubation of islets with $5 \mu \mathrm{mol} / 15$-Edu.

CatL protease activity measurements The mice were simultaneously injected intravenously with a ProSense680 probe ( $1 \mathrm{nmol} / 150 \mu \mathrm{l}$ PBS; PerkinElmer, Waltham, MA, USA) and intraperitoneally with $250 \mu \mathrm{g}$ anti-serpin B13 mAb or IgG control. Mice were euthanised $24 \mathrm{~h}$ later, after which their pancreases and livers were dissected and imaged using IVIS Spectrum In Vivo image system (PerkinElmer). To measure CatL activity in vitro, approximately $10 \mathrm{mg}$ of pancreatic tissue was lysed in CL Buffer and examined using the Cathepsin L Activity Fluorometric Assay Kit (BioVision, Milpitas, CA, USA). The fold increase in CatL activity was determined 


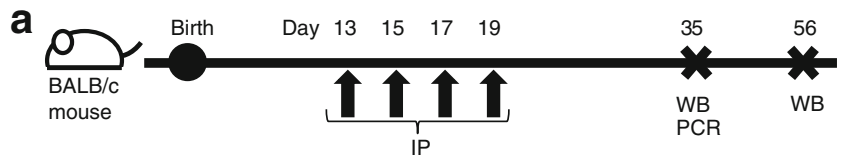

Serpin B13 mAb (clone B29) or lgG

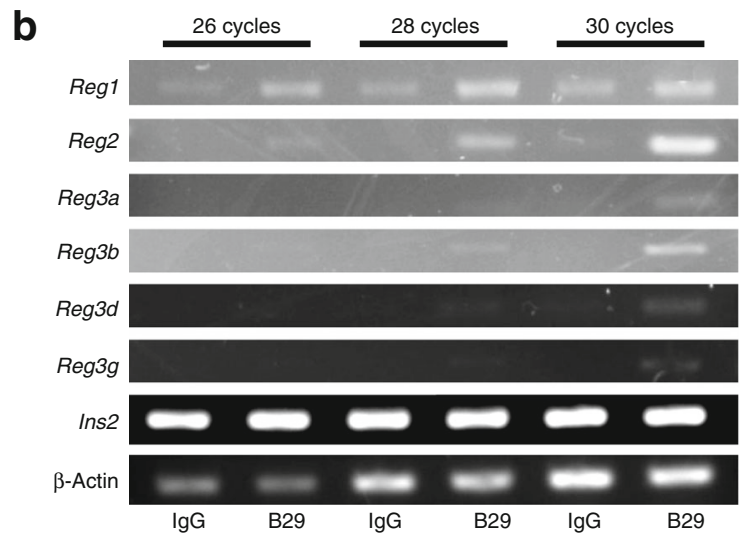

C
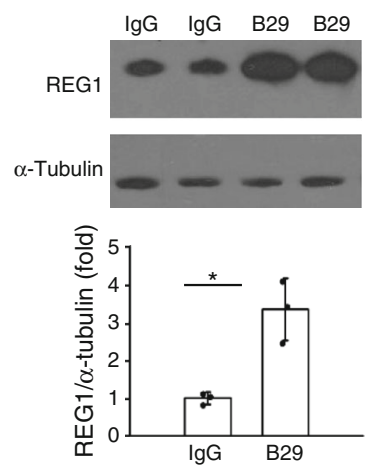

d

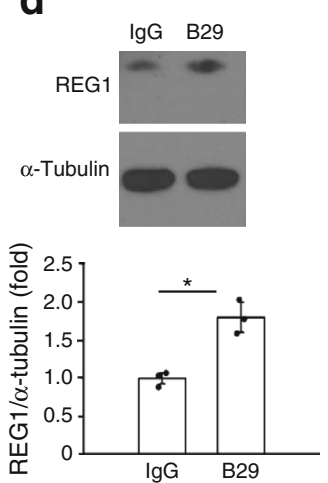

Fig. 1 REG gene expression is upregulated in pancreatic islets following inhibition of serpin B13. (a) Experimental timeline. Thirteen-day-old healthy BALB/c mice were injected intraperitoneally four times with $25 \mu \mathrm{g}$ of serpin B13 mAb (clone B29) or control IgG, as depicted, and euthanised at 5 weeks of age (day 35) for analysis of protein levels by western blotting (WB) or gene expression by PCR, or 8 weeks of age (day 56) for western blotting only. (b) Expression data for several REG genes in 5-week-old mice by semi-quantitative PCR ( $n=4$ mice/group). (c, d) Expression data for REG1 protein in 5-week old (c) and 8-week old (d) mice by western blotting ( $n=3$ mice/group). Representative blots and densitometry analysis are shown. Data are means \pm SD. $* p<0.05$; unpaired Student's $t$ test

using a FLOORstar OPTIMA microplate reader (BioTek, Winooski, VT, USA).

Quantitative real-time PCR Pancreatic islet RNA was prepared using TRIzol reagent (Invitrogen). One microgram of the total islet RNA per group was reverse transcribed to cDNA using the iScript cDNA Synthesis Kit (Bio-Rad, Hercules, CA, USA). Quantitative RT-PCR assays were performed on a Rotor-Gene 3000 System platform using cDNA and the iQ SYBR Green Supermix reagent (Bio-Rad). $\beta$-Actin and glyceraldehyde-3-phosphate dehydrogenase gene amplification were used as the internal control to normalise the data from mice and humans, respectively. The primer sequences were described previously [6].

Flow cytometry Single-cell suspensions were obtained by treating the islets with Cellstripper buffer $\left(5 \mathrm{~min} / 37^{\circ} \mathrm{C}\right)$. To assess beta cell proliferation, the islet cells were fixed and permeabilised using a FOXP3 intracellular staining kit (Biolegend) after they were first stained with the LIVE/DEAD Fixable Violet Dead Cell Stain Kit (Invitrogen) to exclude dead cells from further analysis. The islet cells were stained with Alexa Fluor 647conjugated anti-insulin antibody (1:400; BD Pharmingen, San Jose, CA, USA) and FITC-conjugated anti-Ki67 antibody (1:200; Thermo Fisher, Waltham, MA, USA); alternatively, they were stained with Cy5-azide (Lumiprobe, Hunt Valley, MD, USA) to detect 5-Edu incorporation. To assess apoptosis, the islet cells were stained with the Violet Annexin V/Dead Cell Apoptosis Kit (Invitrogen). Briefly, the dissociated islet cells were stained with Pacific Blue Annexin V and SYTOX AADvanced Dead Cell Stain, according to the manufacture's protocol. The live and necrotic cells showed low and high staining with both dyes, respectively, while the apoptotic cells were single positive and stained with Pacific Blue Annexin V only. To assess E-cadherin expression, the islet cells were fixed and stained with $\mathrm{mAb}$ to E-cadherin at $1 \mu \mathrm{g} / \mathrm{ml}$ (Invitrogen) followed by Alexa Fluor 488-conjugated anti-rat IgG (1:1000; Invitrogen).

Western blotting The islets were lysed in RIPA buffer containing protease inhibitors. After $10 \mathrm{~min}$ of high-speed centrifugation $(18,000 \mathrm{~g})$, protein concentrations were measured in the lysates using the BCA Protein Assay (Thermo Fisher). Equal protein samples (e.g. $10 \mu \mathrm{g}$ per lane) were run on NuPAGE Bis-Tris gels in NuPAGE MOPS buffer or MES running buffer (Invitrogen) and were transferred to a nitrocellulose membrane using the Pierce Fast Semi-Dry Blotter system (Thermo Fisher). After transfer, the membranes were stained with primary antibody followed by secondary antibody and were developed using a chemiluminescence detection system (Amersham Biosciences, Little Chalfont, UK).

Statistics Statistical analyses were performed using the Student's $t$ test, one-way ANOVA and the Dunnett's test. A $p$ value $<0.05$ was used to indicate significance. The data are presented as the mean $\pm \mathrm{SD}$.

\section{Results}

Targeting exocrine pancreatic ducts with anti-serpin B13 mAb leads to enhanced intra-islet expression of REG genes Serpin 
Table 1 Differential REG gene expression in pancreatic islets

\begin{tabular}{|c|c|c|c|}
\hline $\begin{array}{l}\text { Change in gene } \\
\text { expression }\end{array}$ & Islet diameter $<100 \mu \mathrm{m}$ & Islet diameter $100-200 \mu \mathrm{m}$ & Islet diameter $>200 \mu \mathrm{m}$ \\
\hline $\begin{array}{l}\text { Upregulated } \\
\text { genes }^{\mathrm{a}}\end{array}$ & $\begin{array}{l}\text { Reg2, Reg3a, Reg3b, Reg3d, Acta2, } \\
\text { Bcl9l, Bcor, Brd3, C87436, Cabp2, Cart, } \\
\text { Celsr2, Cldn10, Crlf1, Csrp2, Efcab4a, } \\
\text { Hamp2, Klk1b27, Klk1b5, Man2b1, } \\
\text { Mknk1, Npm3, Nsun4, Pak3, Peg3, } \\
\text { Pik3r1, Ppcs, Psma4, Psmb7, Ptf1a, } \\
\text { Ptpn21, Rab7, Rabl3, Rilpl1, Rnf44, } \\
\text { Sirt3, Slc39a11, Slc39a5, Sorl1, } \\
\text { St } 3 \text { gal6, St 6 gal1, Taf15, Tff2, Tle6, } \\
\text { Tmem176a, Trim41, Trip12, Ufsp2, } \\
\text { Uqcrc2, Usp20, Vps26, 1110059G02Rik, } \\
\text { 1810009J06Rik, 2010107E04Rik, } \\
\text { 2310007F21Rik, 2510009E07Rik, } \\
\text { A330068P14Rik, C430003P19Rik, } \\
\text { F730003H07Rik, LOC100047800, } \\
\text { LOC386112, LOC386360 }\end{array}$ & $\begin{array}{l}\text { Reg1, Reg2, Acta2, Adrbk2, Aqp1, Arhgdib, } \\
\text { Cd52, Cd69, Cd72, Cd74, Cd79b, Cdca4, } \\
\text { Chmp4b, Coro1a, Cpa2, Cxcl13, Cytip, } \\
\text { Dmbt1, Faim3, Fcrla, Gde1, H2-Ab1, } \\
\text { H2-DMb1, H2-DMb2, H2-Ea, H2-Eb1, } \\
\text { Hvcn1, Igh-6, Igh-VJ558, Igk-C, Igl-V1, Il4i1, } \\
\text { Klhl6, Laptm4a, Laptm5, Lrmp, Lrp12, Lyz, } \\
\text { Lyz2, Mfge8, Mrpl53, Napsa, Ncf4, Ndufa9, } \\
\text { Neurog3, Nip7, Npm1, Nudt11, Pcgf5, Pde4b, } \\
\text { Pla2g1b, Pou2af1, Prss2, Psmd1, Sdcbp, } \\
\text { Serpina1b, Symbol, Thada, Vwf, Zfp36l1, } \\
\text { Zfp445, Znrd1, 2010001M09Rik, } \\
\text { 2210419D22Rik, 2310009A05Rik, } \\
\text { E430033B07Rik, EG386551, } \\
\text { ENSMUSG00000043795, LOC100040233, } \\
\text { LOC100041567, LOC100047162, } \\
\text { LOC100047208, LOC100047628, } \\
\text { LOC100047815, LOC243439, LOC386520, } \\
\text { LOC635601, LOC635601, LOC641240, } \\
\text { LOC665506, LOC676136 }\end{array}$ & $\begin{array}{l}\text { Aadacl1, Abcf1, Alg1, Amotl1, Anxa11, } \\
\text { Arpc3, Dnajc16, Echdc2, F2r, Fndc3b, } \\
\text { Fntb, Hspa9, Iap, Klf7, Lyz, Mkln1, } \\
\text { Nxph1, Pfdn4, Ppid, Rabl2a, Sar1b, } \\
\text { Sc4mol, Smek1, Sncg, St5, Tmsb10, } \\
\text { Trub2, Yifla, 1110002N22Rik, } \\
\text { 4921514E18Rik, LOC100040592 }\end{array}$ \\
\hline $\begin{array}{l}\text { Downregulated } \\
\text { genes }^{\mathrm{b}}\end{array}$ & $\begin{array}{l}\text { Actb, Amigo3, Arc, Atf3, Axud1, Bxdc2, } \\
\text { Cish, Ddit3, Ddit3, Eml1, Errfil, Gdi1, } \\
\text { Hbb-b1, Impact, Junb, Kbtbd2, Lmna, } \\
\text { Narg1l, Nfkbiz, Npas4, Nudc-ps1, } \\
\text { Palmd, Socs3, Zfand2a, Zfc3h1, } \\
\text { 0610010105Rik, 1700015E05Rik, } \\
\text { 2310008M10Rik, 4930539E08Rik, } \\
\text { LOC100045567, LOC100047184, } \\
\text { LOC100047261, LOC100047353 }\end{array}$ & $\begin{array}{l}\text { Cish, Cited 2, Fam135a, Folr1, Hspala, Klf7, } \\
\text { Phlda1, Ppy, 6030400N17Rik, AU040829 }\end{array}$ & $\begin{array}{l}\text { Reg1, Akap9, Amy2, Amy2-2, Angel2, } \\
\text { Arrdc4, Birc2, Bxdc5, Cdc5l, Cel, Cenpt, } \\
\text { Cish, Clps, Cpa1, Cpa2, Cpb1, Csmd2, } \\
\text { Ctrb1, Ctrc, Ctrl, Cuzd1, Dars, Dctn5, } \\
\text { Dmbt1, Dnajc30, Dnajc6, Dpp4, } \\
\text { Dusp11, Eif2s3x, Ela1, Ela2a, Ela3b, } \\
\text { Errfil, Etfa, Extl2, Farsb, Fbxo3, Gnao1, } \\
\text { Gp2, Hnrnpa2b1, Hsf1, Idh1, Klk1, } \\
\text { Klk1b26, Klk1b27, Klk1b4, Klk1b5, } \\
\text { Marveld3, Mpp3, Mtch2, Mtf1, } \\
\text { Ncrna00117, Nfyc, Nme5, Nudt5, Nupr1, } \\
\text { Paox, Pcmt1, Pde6d, Pdia2, Pex11a, } \\
\text { Pigx, Pla2g1b, Pnlip, Pnliprp1, } \\
\text { Pnliprp2, Ppap2b, Ppapdc1b, Ppp2ca, } \\
\text { Ppp6c, Prss2, Prss3, Rdh14, Rnase1, } \\
\text { Rnf19a, Rnf34, Scgn, Sfrs11, Sin3a, } \\
\text { Slc40a1, Smc1a, Spink3, Spon2, Sycn, } \\
\text { Tbc1d20, Tff2, Tpst1, Try10, Try4, } \\
\text { Tsc22d1, Tssc1, Zfyve21, } \\
\text { 1810010M01Rik, 1810028F09Rik, } \\
\text { 1810049H19Rik, 2010004M13Rik, } \\
\text { 2210010C04Rik, 2610101N10Rik, } \\
\text { 2610302F08Rik, 4921518A06Rik, } \\
\text { 6030400N17Rik, BC017158, } \\
\text { D6Wsu163e, EG386551, EG436523, } \\
\text { EG623818, LOC100040233, } \\
\text { LOC100045542, LOC100047208, } \\
\text { LOC380844 }\end{array}$ \\
\hline
\end{tabular}

Microarray analysis was performed using the total RNA isolated from pancreatic islets according to islet size in 5-week-old mice previously treated with serpin B13 mAb or IgG ( $n=6$ /group). The mice were treated with serpin B13 mAb exactly as described in Fig. 1a

${ }^{a} \mathrm{~B} 29 / \mathrm{IgG}$ fold change $>2$

${ }^{\mathrm{b}} \mathrm{B} 29 / \mathrm{IgG}$ fold change $<0.5$

B13 is expressed in the exocrine pancreatic ducts [1]. To examine whether endocrine cells respond to Serpin B13 inhi bition in this tissue compartment, we used anti-serpin B13
$\mathrm{mAb}$. This $\mathrm{mAb}$ blocks the inhibitory function of serpin B13 and causes a partial increase in the activity of its target protease, CatL [1]. Furthermore, our anti-serpin B13 mAb is 
Fig. 2 REG proteins mediate beta cell proliferation following islet with inhibited serpin B13. (a) Experimental design. Freshly isolated pancreatic islets were cultured in vitro for $48 \mathrm{~h}$ with Capan-2 cell lysate, either alone or in combination with serpin B13 $\mathrm{mAb}$ (clone B29) or control IgG and were harvested for analysis as indicated. (b) Quantitative PCR analysis of REG gene expression in mouse islets. (c, d) Beta cell proliferation in mouse (c) and human (d) islets (flow cytometry analysis of insulin ${ }^{+} / \mathrm{Ki} 67^{+}$or 5 -

Edu double-positive cells). (e)

Effect of neutralising antibodies (Abs) to REG1, REG2 and REG3D ( $4 \mu \mathrm{g} / \mathrm{ml}$ each) on augmented proliferative response to serpin B13 mAb in mouse. (f) Apoptosis levels (flow cytometry analysis of Annexin $\mathrm{V}^{+} / 7-\mathrm{AAD}^{-}$ cells) of mouse islets cells treated with Capan-2 cell lysate and/or serpin B13 mAb. For all studies three independent experiments were performed and biological used in each experiment. Data are

$* * p<0.01$ and $* * * p<0.001$; ANOVA followed by Dunnett's test for multiple comparisons with control (b, c, e, f), and unpaired Student's $t$ test (d) exposure to ductal cell extract duplicates ( $n=2$ /group) were means \pm SD. $* p<0.05$,

a
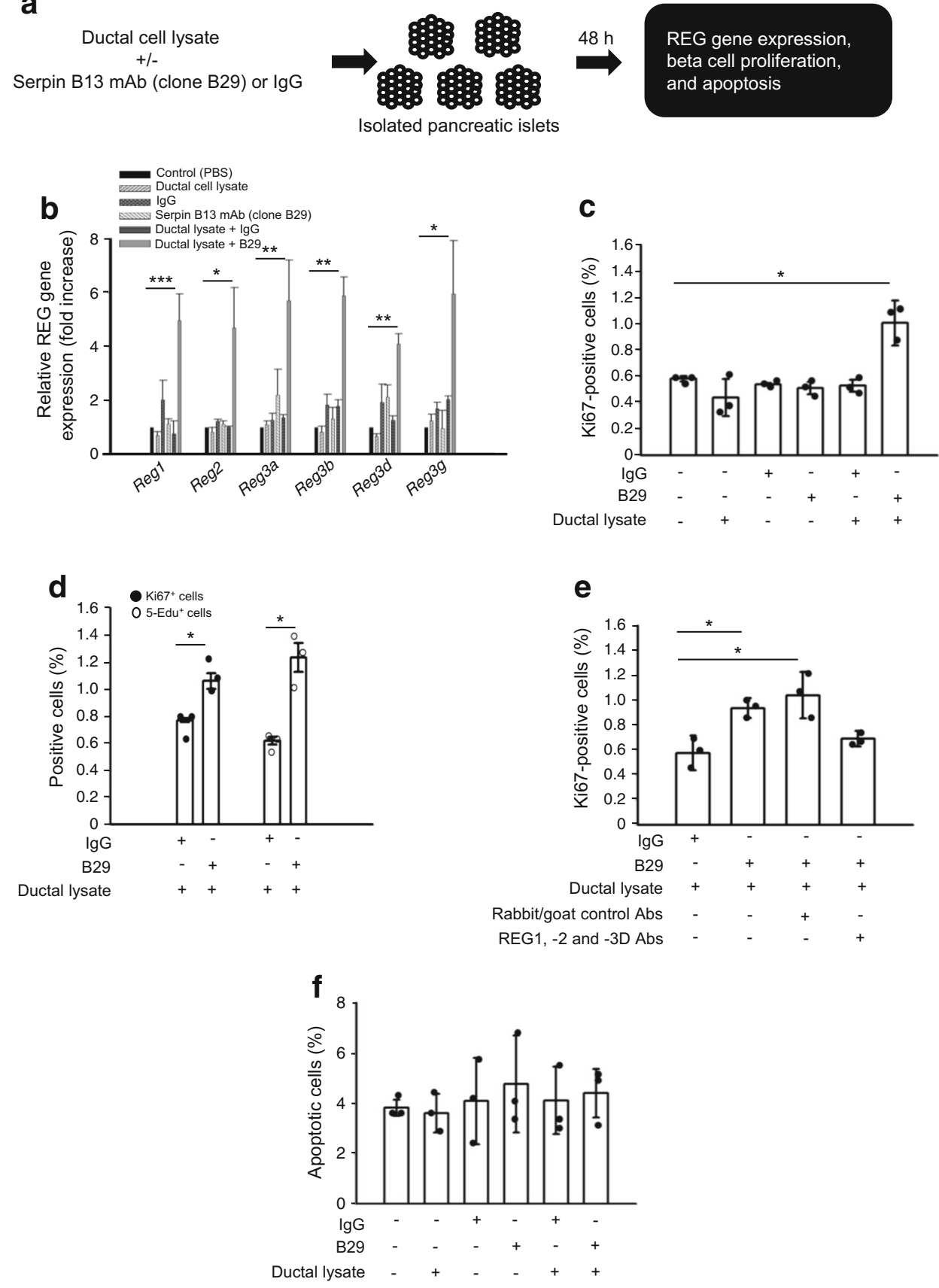

specific, as it fails to recognise other members of clade B family (see electronic supplementary material [ESM] Fig. 1). By using oligonucleotide microarray technology, we found that inhibiting serpin B13 in healthy BALB/c mice treated with a mAb according to our protocol (Fig. 1a) resulted in upregulation of REG genes (Table 1) that have been implicated in beta cell proliferation [14-16]. This upregulation was noted in the small and intermediate-sized islets measuring less than $200 \mu \mathrm{m}$ in diameter (Table 1 and ESM Fig. 2) and persisted for several weeks after discontinuation of treatment with anti-serpin B13 mAb (Fig. 1b-d).
REG proteins mediate beta cell proliferation in response to augmented crosstalk between ductal epithelium and islets To ascertain the significance of intra-islet REG gene upregulation following inhibition of serpin B13, we have developed an in vitro experimental system consisting of pancreatic islets cultured with ductal cell extract (e.g. Capan2 cells), which expresses this serpin (ESM Fig. 3), in the presence of anti-serpin B13 mAb (Fig. 2a). Our mAb, clone B29, binds human and mouse variant of serpin B13 [1] and does not cause compensatory upregulation of other clade B serpins (ESM Fig. 4). We found that only 
Fig. 3 Serpin B13 inhibition stimulates CatL protease activity in the pancreas. (a) CatL protease activity of the total pancreatic cell lysate, measured as described in Methods, incubated with increasing concentrations of antibodies, as indicated. Biological duplicates $(n=2$ per each antibody concentration) were used. (b, c) A representative image demonstrating fluorescence intensity of the pancreatic (b) and hepatic (c) tissue in healthy wild-type $\mathrm{BALB} / \mathrm{c}$ mice treated with serpin B13 mAb (clone B29) or IgG control. Liver tissue, which does not express serpin B13, was used as an additional control. The fluorescence intensity shown corresponds to radiant efficiency described as $\left(\mathrm{p} \mathrm{s}^{-1} \mathrm{~cm}^{-2} \mathrm{sr}^{-1}\right) /$ $\left(\mu \mathrm{W} / \mathrm{cm}^{2}\right)$. (d, e) Quantitative analysis of experiments, similar to that depicted in (b) and (c), performed in wild-type $(n=5 /$ group) (d) and CatL-deficient (KO) BALB/c mice ( $n=3 /$ group) (e). (f) CatL protease activity, measured as described in Methods, of the total pancreatic cell lysate obtained from wildtype (WT) and CatL-deficient mice ( $n=4$ mice/group). Results in (d), (e) and (f) are expressed as relative fluorescence intensity. Two independent experiments were performed. The combined data from independent experiments are shown. Data are means \pm SD. $* p<0.05$, and $* * * p<0.001$; ANOVA (a) and unpaired Student's $t$ test $(\mathbf{d}, \mathbf{e}, \mathbf{f})$ a

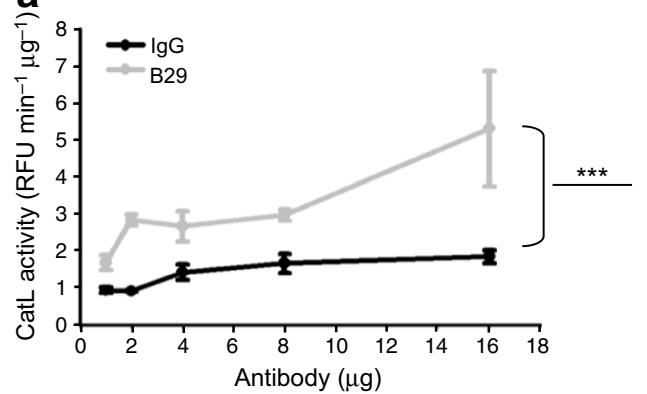

b

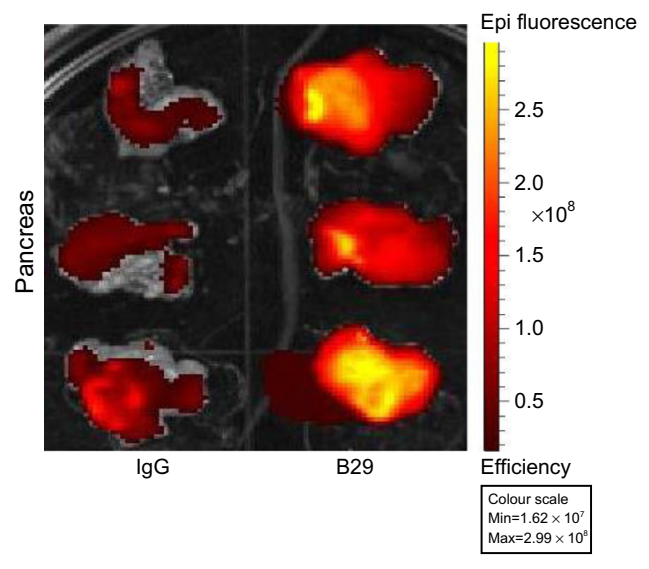

C

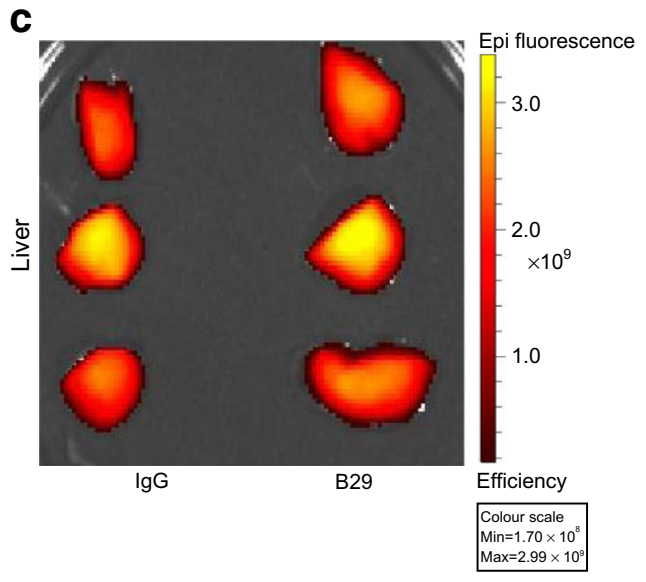

d
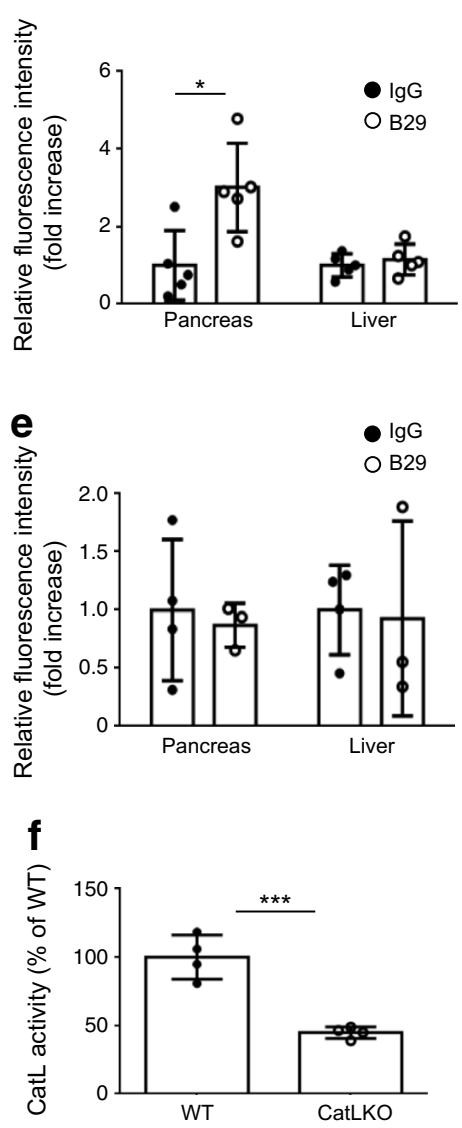

a combination of the ductal cell extract and anti-serpin $\mathrm{B} 13 \mathrm{mAb}$ induced REG gene upregulation and beta cell proliferation in cultured islets (Fig. 2b, c and ESM Fig. $5 a)$; treatment with anti-serpin B13 mAb or Capan-2 cell extract alone failed to induce these changes. Augmented REG gene expression began to occur after $24 \mathrm{~h}$ of islet incubation and preceded the enhancement of beta cell proliferation, which was observed after 48-72 h of incubation (ESM Fig. 5a, b). Human islets also demonstrated increased REG gene expression [6] and cellular proliferation in response to incubation with an extract of Capan-2 cells treated with anti-serpin B13 mAb, compared with incubation with ductal epithelium extract treated with control IgG (Fig. 2d). Importantly, the augmented beta cell proliferation observed in our in vitro experimental system was sensitive to the neutralising effect of antibodies against several REG proteins (e.g. REG1, REG2 and REG3D) implicating these molecules as a link between the exocrine ductal epithelium and enhanced beta cell renewal in the islets (Fig. 2e). On the other hand, the percentage of beta cells undergoing apoptosis remained unchanged in the islets exposed to Capan- 2 cell extract and anti-serpin B13 mAb, compared with control groups (Fig. 2f). This finding suggests that the REG-dependent 
a
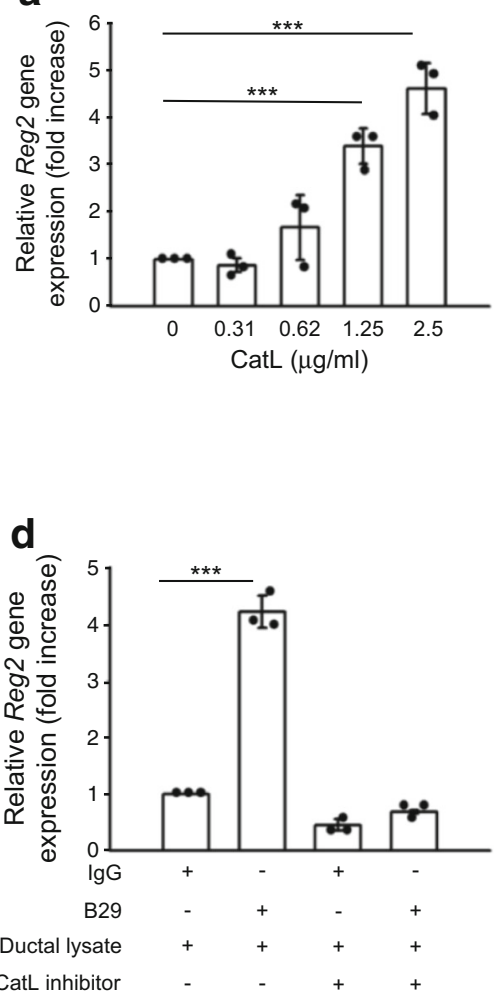

g

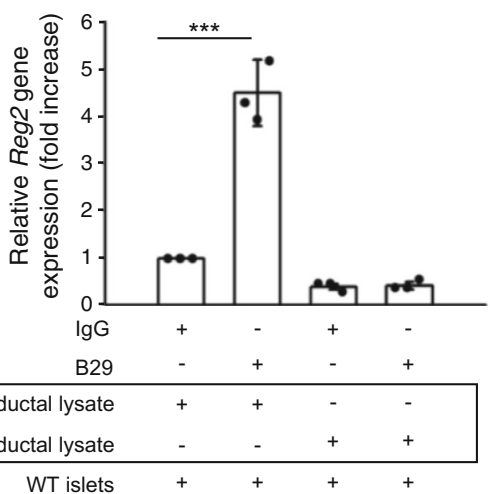

Fig. 4 CatL is necessary for serpin B13 mAb-induced REG gene expression and proliferation of beta cells. (a) Reg2 gene expression analysis by quantitative PCR. Isolated islets were incubated with increasing concentrations of CatL, as indicated, for $4 \mathrm{~h}$, and were harvested after $48 \mathrm{~h}$ of culture for analysis. (b-f) Beta cell proliferation and REG gene expression in the islets treated for $4 \mathrm{~h}$ with CatL $(2.5 \mu \mathrm{g} / \mathrm{ml})$ or Capan- 2 cell lysate and serpin B13 mAb (clone B29) or IgG control, in the presence or absence of protease inhibitor E64 $(20 \mu \mathrm{g} / \mathrm{ml})(\mathbf{b}, \mathbf{c})$, or inhibitors of CatL, Z-FY-CHO $(10 \mu \mathrm{mol} / \mathrm{l})$ (d [mouse], e [human]) and cathepsin B (CatB), Ac-LVK-CHO $(4 \mu \mathrm{mol} / \mathrm{l})(\mathbf{f})$, as indicated. After a $48 \mathrm{~h}$ incubation period, the islets were harvested for analysis. (g, h) Reg2 gene expression in islets incubated as indicated. Incubation of islets isolated from wild-type mice
C

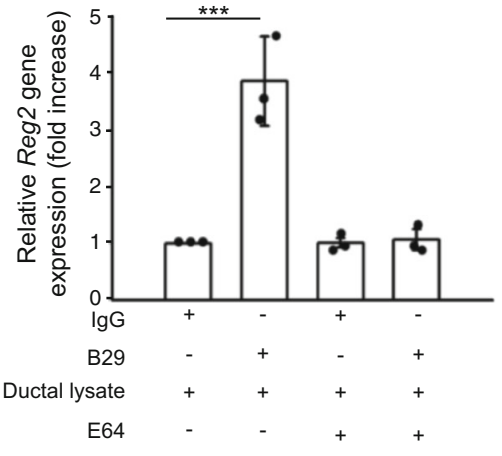

f



h

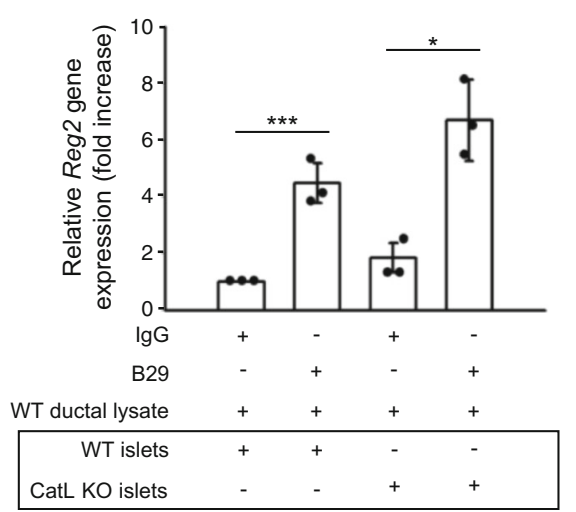

included adding lysates of pancreatic primary ductal epithelium isolated from either wild-type (WT) or CatL-deficient (KO) mice (g). Alternatively, incubation of islets isolated from either WT or CatL KO mice included addition of primary ductal cell lysate that had been obtained from WT mice only (h). The islets were harvested and examined at the end of the culture period, as in (a). For all studies, three independent experiments were performed and biological duplicates ( $n=2$ /group) were used in each experiment. The combined data from independent experiments are shown. Data are means \pm SD. $* p<0.05, * * p<0.01$, and *** $p<0.001$; ANOVA followed by Dunnett's test for multiple comparisons $(\mathbf{a}, \mathbf{b})$ and pairwise comparison by $t$ test $(\mathbf{c}-\mathbf{h})$

CatL protease activity is markedly upregulated by inhibiting intrapancreatic serpin B13 CatL has been implicated as a

potentiation of beta cell replicative activity we observed was not caused by in vitro islet cell death. 
serpin B13 protease target $[2,3]$. Consistent with this, we found that our anti-serpin B13 mAb interferes with the inhibitory activity of serpin B13 against CatL in vitro [1]. To further examine the consequences of inhibiting serpin B13 using $\mathrm{mAb}$, we examined the catalytic activity of CatL. First, we noted that anti-serpin B13 mAb dose-dependently enhanced the protease activity of CatL when added to a cell extract representative of total pancreatic tissue (Fig. 3a). Second, using the activity-based probe, ProSense 680 [17], we observed a significant increase in cathepsin activity in intact pancreas following injection of anti-serpin $\mathrm{B} 13 \mathrm{mAb}$ into mice (Fig. 3b). This increase was limited to the pancreas in wild-type BALB/c mice and was not observed in the liver, in which serpin B13 is not expressed (Fig. 3c, d); nor was the increase observed in the pancreas of CatL-deficient BALB/c mice (Fig. 3e, f). Together, these data demonstrate that serpin $\mathrm{B} 13$ inhibition with a functional $\mathrm{mAb}$ provides a reliable model of this serpin inhibition thereby allowing us to examine in more detail the contribution of elevated CatL protease activity to the crosstalk between exocrine and endocrine pancreatic tissue.

Exogenous CatL is responsible for upregulated REG gene expression and proliferation of insulin-producing cells To directly examine the impact of CatL on the endocrine pancreas, we exposed islets to this protease for several hours. We noted that both REG gene expression (Fig. 4a and ESM Fig. 6a) and beta cell proliferation (Fig. 4b) was augmented following this treatment. Moreover, the increased REG gene expression in islets that had been cultured with an extract of Capan- 2 cells treated with serpin $\mathrm{B} 13 \mathrm{mAb}$, was completely blocked in the presence of E64, an inhibitor of several proteases (Fig. 4c and ESM Fig. 6b); Z-FY-CHO, a highly selective CatL inhibitor, had the same effect (Fig. 4d, e and ESM Fig. 6c). In contrast, no inhibition of REG gene upregulation was observed in the presence of Ac-LVK-CHO, an inhibitor of cathepsin B, which is not affected by serpin B13 (Fig. 4f and ESM Fig. 6d). Finally, similar to results obtained with chemical inhibitors, pancreatic islets failed to display increased REG gene expression when CatL-deficient mice were used as the source of pancreatic primary ductal cells (Fig. 4g and ESM Fig. 6e). In contrast, CatL-deficient pancreatic islets maintained their ability to upregulate REG genes (Fig. 4h and ESM Fig. 6f). Collectively, these data provide evidence for the central role of extra-islet CatL in bridging the exocrine pancreas to the regeneration of pancreatic islets.

CatL stimulates REG expression through inhibition of Ecadherin and activation of $\beta$-catenin signalling E-cadherin, which is expressed in pancreatic islets $[18,19]$, has been shown to inhibit signalling by sequestering $\beta$-catenin [20]. Increased levels of E-cadherin during islet formation mediate a decline in the rate of beta cell proliferation [21] and REG upregulation has been linked to the activation of $\beta$-catenin $[22,23]$. We therefore hypothesised that the functional crosstalk between pancreatic ductal epithelium and beta cell proliferation may involve CatL-mediated activation of the Ecadherin- $\beta$-catenin pathway. Indeed, by using two independent readouts in healthy BALB/c mice that had been injected with serpin $\mathrm{B} 13 \mathrm{mAb}$, according to the protocol depicted in Fig. 1a, we observed E-cadherin downregulation and a concomitant increase in REG1 expression (Fig. 5a, b). Moreover, we found that both CatL (Fig. 5c) and Capan-2 cell extract treated with serpin B13 mAb (Fig. 5d, e) caused a marked decrease in E-cadherin expression in mouse and human pancreatic islets in vitro. On the other hand, E-cadherin expression was rescued when a CatL inhibitor, Z-FY-CHO, was added to these islet cultures (Fig. $5 \mathrm{~d}$, e). To determine the sequelae of E-cadherin inhibition, we blocked its function with mAb (Fig. 5f) or EGTA (ESM Fig. 7) and found that these treatments caused marked upregulation of REG genes. Importantly, inhibition of serpin B13 with mAb (clone B29), which also upregulates REG, resulted in marked nuclear accumulation of $\beta$-catenin in insulinoma cells (Fig. 5g). Finally, augmentation of REG gene expression in the islets by B29 in our in vitro culture system was reduced in the presence of the $\beta$-catenin inhibitor, FH535 (Fig. 5h and ESM Fig. 8), suggesting a role for the E-cadherin- $\beta$-catenin pathway in the response of islets to signals generated in the exocrine milieu.

\section{Discussion}

In this study we elucidated a novel pathway of intrapancreatic communication between exocrine ductal tissue and endocrine islet cells. We found this pathway to be dependent on the presence of extracellular CatL and the subsequent cleavage of E-cadherin in the islets - an event that we believe leads to significant upregulation of intra-islet REG gene expression and a consequent increase in cell proliferation (Fig. 6). Although our study was primarily focused on beta cells, we cannot exclude the possibility that a similar proliferative response is evoked in other endocrine cell types in the islets. Of note, the islets used in our in vitro system were size-matched and were not limited to small islets, which were more sensitive than larger islets to serpin B13 inhibition in vivo. This variation between two experimental settings was justified by the fact that we used a relatively high concentration (50\%) of the ductal epithelium extract to culture the islets, thereby increasing the chances of equal penetration of signals generated in the extract to all islets, regardless of their size.

Involvement of E-cadherin as the downstream target of ductalderived CatL activity and of REG molecules as downstream propagators of the E-cadherin- $\beta$-catenin pathway is consistent with the well-documented roles cadherins $[18,24,25]$ and REG proteins $[26,27]$ play in islet biology. Diminished E- 

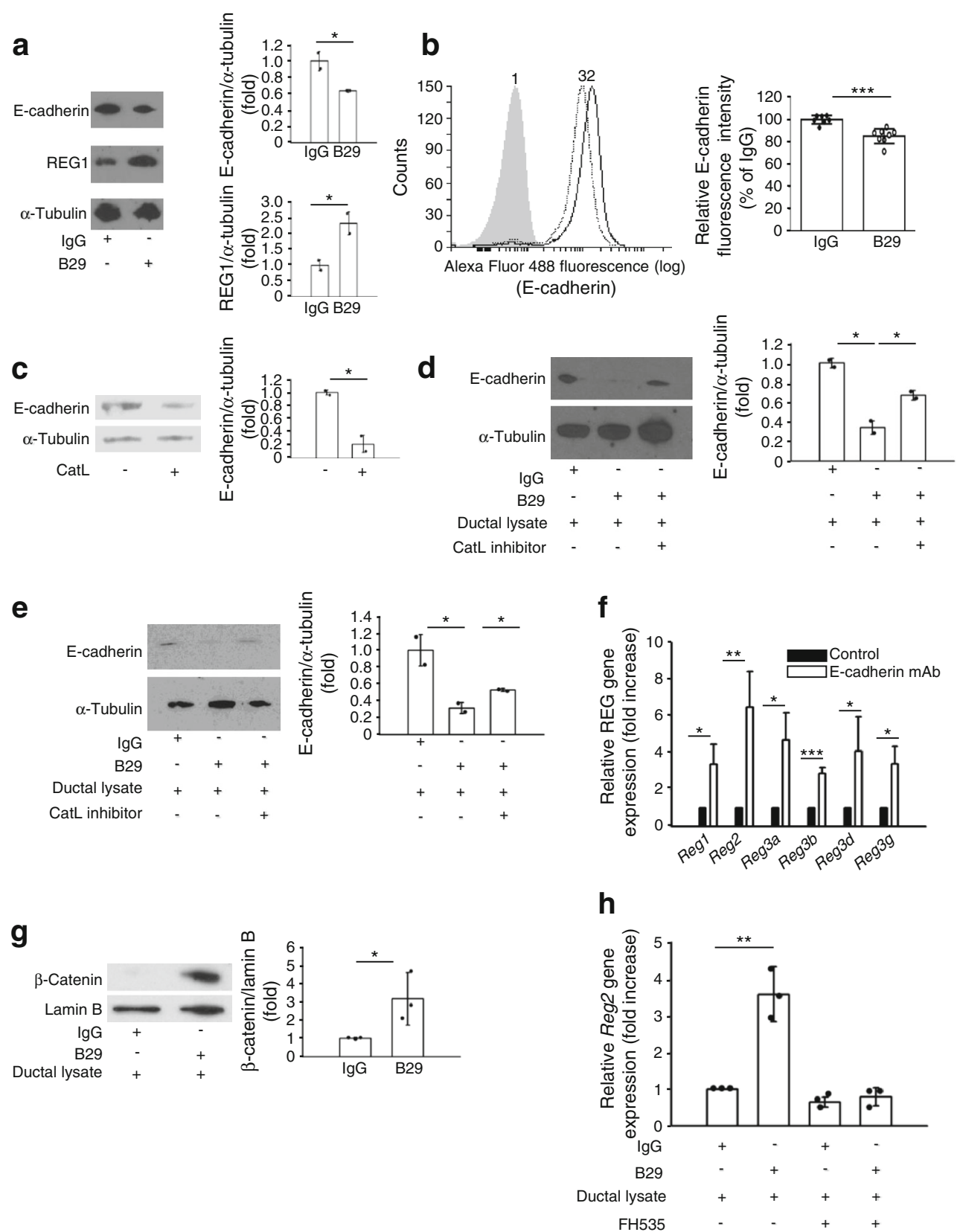

Fig. 5 E-cadherin downregulation during serpin B13 inhibition promotes expression of REG. (a, b) Western blotting of E-cadherin and REG1 (a) and flow cytometry analysis of E-cadherin (b) in healthy wild-type BALB/c mice treated with antibodies as described in Methods. Two weeks after the last injection, 5-week-old mice (IgG, $n=7$; B29, $n=8)$ were euthanised and their islets were isolated for the analysis. Two independent experiments were performed. Representative blots and densitometry analysis of blots are shown in (a). Representative flow cytometry data are shown in (b). Distribution 1 depicts staining with a secondary antibody only; distribution 2 depicts mice treated with IgG; and distribution 3 depicts mice treated with serpin B13 mAb (clone B29). Quantitative analysis of flow cytometry from all mice using mean channel fluorescence intensity to compare $\operatorname{IgG}$ and B29-treated groups is shown in (b). (c-e) Western blot analysis of E-cadherin in cultured mouse (c, d) and human (e) pancreatic islets that were treated for $4 \mathrm{~h}$ with recombinant CatL $(2.5 \mathrm{ng} / \mathrm{ml})$ (c) or a combination of Capan- 2 cell lysate and IgG, or B29 mAbs with or without the CatL inhibitor Z-FY-CHO $(10 \mu \mathrm{mol} / \mathrm{l})$, for $48 \mathrm{~h}(\mathbf{d}, \mathbf{e})$. Representative blots and densitometry analysis of blots are shown. Two independent experiments were performed. (f) REG gene expression (measured by quantitative PCR) in pancreatic islets incubated for $48 \mathrm{~h}$ with E-cadherin neutralising $\mathrm{mAb}(2 \mu \mathrm{g} / \mathrm{ml}$, clone DECMA-1) or purified rat polyclonal IgG antibody (control). Three independent experiments were performed. (g) Western blotting analysis of $\beta$-catenin nuclear fractions in MIN6 cells. Cells were cultured with the lysate of Capan-2 cells and either control $\mathrm{IgG}$ or the B29 clone for $48 \mathrm{~h}$. The nuclear proteins were isolated using NE-PERNuclear and Cytoplasmic Extraction Reagent (Thermo Scientific) and then stained with $\beta$-catenin and lamin B antibodies. Representative western blots and densitometry analysis are shown. Three independent experiments were performed. (h) Reg2 gene expression (measured by quantitative PCR) in pancreatic islets incubated for $48 \mathrm{~h}$ with the Capan-2 cell lysate and B29 mAb (or IgG control) and the Wnt/ $\beta$-catenin inhibitor, FH535 $(20 \mu \mathrm{mol} / \mathrm{l})$. Three independent experiments were performed. Biological duplicates ( $n=2 /$ group) were used in each in vitro experiment. The combined data from independent experiments are shown. Data are means \pm SD. $* p<0.05, * * p<0.01$, and $* * * p<0.001$; unpaired Student's $t$ test $(\mathbf{a}-\mathbf{c}, \mathbf{f}-\mathbf{g})$ and pairwise comparison by $t$ test $(\mathbf{d}-\mathbf{e}, \mathbf{h})$ 
cadherin expression $[21,28]$ and overexpression of REG [14-16] have been proposed to stimulate beta cell proliferation. In addition, observations that protease-mediated cleavage of E-cadherin abolishes the inhibitory effect of E-cadherin on $\beta$-catenin signalling [29], and that the latter is linked to REG overexpression in embryonic stem cells and human liver tumours $[22,23]$, further underpin the model in which unlocking signalling downstream of E-cadherin contributes to exocrine-to-endocrine crosstalk in the pancreas.

The role of CatL in islet biology and type 1 diabetes is debatable. CatL is a potent protease and it is likely that the intensity, duration and location of its proteolytic activity are critical to clinical outcome. Although studies involving the total knockout of CatL [30] and other cathepsins [31] in the NOD mouse model have implicated these proteases as culprits of autoimmune inflammation, additional studies on cathepsins expressed in islets [32] suggest that these molecules can also be protective in type 1 diabetes. The findings presented here, together with our previously published studies $[1,6,12]$, favour a scenario wherein a limited and transient increase in CatL activity in the exocrine pancreas is a desired event providing an initiating stimulus for islet cell proliferation. Whether a transient decline in CatL activity leads to the opposite outcome (e.g., reduced islet-cell proliferation) remains unknown, as mice with conditional CatL knockdown are not available. Thus far, we have not observed significant proliferative changes in the pancreas using complete CatL knockdown, raising the possibility that other proteases might compensate for CatL deficiency in this context.

Although CatL is primarily confined to lysosomes in the cell, it has been suggested that $5-10 \%$ of proteins in this intracellular compartment are missorted to enter the secretory pathway and reach the extracellular environment [33-35]. In certain cell types, CatL has been reported to be secreted and to participate in proprotein processing and remodelling of the extracellular matrix [36]. Similarly, cancer cells can release CatL to the extracellular environment where it promotes tumour invasion, angiogenesis and metastasis [37]. In addition, CatL plays a role in the homing of endothelial progenitor cells to ischaemic areas and formation of new vessels in the heart - a process that requires limited extracellular matrix degradation [38]. Together these examples of secretory CatL degradomic activity are consistent with the proposed role of extracellular pancreatic CatL in beta cell proliferation described in this study. Similar to CatL, clade B serpins have been described primarily as intracellular molecules. However, serpin B1 is released from keratinocytes exposed to UVB light [39] and serpin B13 functions in the extracellular matrix to suppress angiogenesis [40], indicating that these serpins can be released under certain conditions. In addition, we found that serpin B13 can reach the extracellular milieu during culture of embryonic pancreas explants on fibronectin-coated plates (data not shown).

Our study expands a growing list of mechanisms that have been proposed to underlie stimulation of beta cell turnover [39, 41-43] - a slow kinetic process during adulthood [44]. One advantage of our approach is its practicality, which stems from the use of an inhibitory antibody to serpin B13 as a negative regulator of CatL. Autoantibodies that interfere with enzyme cascades have been described by others [45, 46]. In line with these observations we propose that passive immunisation with a mAb, or exposure to endogenous antiserpin B13 autoantibodies, could tip the balance between this serpin and its protease target in favor of the latter. The significance of this approach is highlighted by our recent publication in which we report that individuals with recentonset type 1 diabetes who have autoantibodies to serpin B13 maintain higher C-peptide levels than individuals who do not have these autoantibodies [6]. Moreover, according to our recent unpublished observations, expression of serpin B13 autoantibodies in non-diabetic children with elevated risk for type 1 diabetes is associated with longer diabetesfree survival and significant reduction in the overall incidence of diabetes (Kryvalap and Czyzyk, unpublished observations). This surprisingly strong phenotype in humans could be explained by the potential functionality of serpin

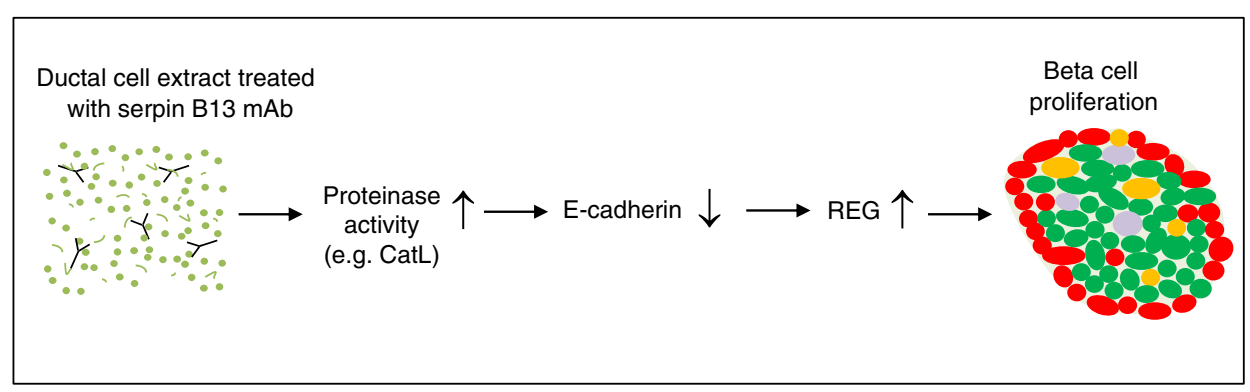

Fig. 6 A model of islet cell proliferation with involvement of the CatL-Ecadherin-REG pathway. Binding of antibodies to serpin B13 neutralises its inhibitory function leading to increased enzymatic activity of its target protease, CatL. The extracellular proteolysis by CatL (or another proteinase compensating if there is CatL deficiency) causes degradation of E-cadherin expressed in the islets, which in turn triggers the proliferation of pre-existing insulin-producing cells in the islets, through partial $\beta$-catenin-mediated upregulation of REG genes 
B13 autoantibodies, which similar to the mAb used in our studies, might stimulate islet regeneration and impede autoimmune inflammation $[1,6,12]$.

In conclusion, a limited increase in CatL activity in the exocrine pancreas provides a multifactorial modality for the health of pancreatic islets. This approach is consistent with the growing notion of a potential contribution of the exocrine pancreas in type 1 diabetes, as both reduced pancreas weight [47], and other changes in the exocrine pancreatic tissue [48] have been described in individuals with this disease.

Acknowledgements Some of the data were presented as abstracts at the ADA 77th and 78th Scientific Sessions in 2017 and 2018, respectively.

Data availability Microarray data that support the findings of this study have been deposited in Gene Expression Omnibus (GEO) with the accession no. GSE125151.

Funding This work was supported by the Juvenile Diabetes Research Foundation Grant no.17-2013-428 and the American Diabetes Association Grant no. 1-17-ICTS-083 (awarded to JC).

Duality of interest The authors declare that there is no duality of interest associated with this manuscript.

Contribution statement $\mathrm{C}$-WL designed and performed experiments, analysed the data and helped to write, edit and review the manuscript. YK and T-JS helped to design experiments and interpret results. C-HC was responsible for analysing microarray data. JC designed experiments, interpreted results and wrote the manuscript. All authors participated in drafting the article and gave their final approval. JC is responsible for the integrity of the work as a whole.

Publisher's note Springer Nature remains neutral with regard to jurisdictional claims in published maps and institutional affiliations.

\section{References}

1. Baldzizhar R, Fedorchuk C, Jha M, Rathinam C, Henegariu O, Czyzyk J (2013) Anti-serpin antibody-mediated regulation of proteases in autoimmune diabetes. J Biol Chem 288(3):1612-1619. https://doi.org/10.1074/jbc.M112.409664

2. Welss T, Sun J, Irving JA et al (2003) Hurpin is a selective inhibitor of lysosomal cathepsin $\mathrm{L}$ and protects keratinocytes from ultraviolet-induced apoptosis. Biochemistry 42(24):7381-7389. https://doi.org/10.1021/bi027307q

3. Jayakumar A, Kang Y, Frederick MJ et al (2003) Inhibition of the cysteine proteinases cathepsins $\mathrm{K}$ and $\mathrm{L}$ by the serpin headpin (SERPINB13): a kinetic analysis. Arch Biochem Biophys 409(2): 367-374. https://doi.org/10.1016/S0003-9861(02)00635-5

4. Silverman GA, Whisstock JC, Askew DJ et al (2004) Human clade B serpins (ov-serpins) belong to a cohort of evolutionarily dispersed intracellular proteinase inhibitor clades that protect cells from promiscuous proteolysis. Cell Mol Life Sci 61(3):301-325. https://doi. org/10.1007/s00018-003-3240-3

5. Van de Casteele M, Leuckx G, Baeyens L et al (2013) Neurogenin $3^{+}$cells contribute to $\beta$-cell neogenesis and proliferation in injured adult mouse pancreas. Cell Death Dis 4(3):e523. https://doi.org/10. 1038/cddis.2013.52

6. Kryvalap Y, Lo CW, Manuylova E, Baldzizhar R, Jospe N, Czyzyk $\mathrm{J}$ (2016) Antibody response to serpin B13 induces adaptive changes in mouse pancreatic islets and slows down the decline in the residual beta cell function in children with recent onset of type 1 diabetes mellitus. J Biol Chem 291(1):266-278. https://doi.org/10.1074/jbc. M115.687848

7. Terazono K, Yamamoto H, Takasawa S et al (1988) A novel gene activated in regenerating islets. J Biol Chem 263(5):2111-2114

8. Huszarik K, Wright B, Keller C et al (2010) Adjuvant immunotherapy increases $\beta$ cell regenerative factor Reg2 in the pancreas of diabetic mice. J Immunol 185(9):5120-5129. https://doi.org/10. 4049/jimmunol.1001596

9. Pittenger GL, Taylor-Fishwick D, Vinik AI (2009) The role of islet neogeneis-associated protein (INGAP) in pancreatic islet neogenesis. Curr Protein Pept Sci 10(1):37-45. https://doi.org/10. 2174/138920309787315211

10. Pittenger GL, Taylor-Fishwick DA, Johns RH, Burcus N, Kosuri S, Vinik AI (2007) Intramuscular injection of islet neogenesisassociated protein peptide stimulates pancreatic islet neogenesis in healthy dogs. Pancreas 34(1):103-111. https://doi.org/10.1097/01. mpa.0000240609.56806.43

11. Lai Y, Li D, Li C et al (2012) The antimicrobial protein REG3A regulates keratinocyte proliferation and differentiation after skin injury. Immunity 37(1):74-84. https://doi.org/10.1016/j.immuni. 2012.04.010

12. Czyzyk J, Henegariu O, Preston-Hurlburt P et al (2012) Enhanced anti-serpin antibody activity inhibits autoimmune inflammation in type 1 diabetes. J Immunol 188(12):6319-6327. https://doi.org/10. 4049/jimmunol.1200467

13. Reichert M, Takano S, Heeg S, Bakir B, Botta GP, Rustgi AK (2013) Isolation, culture and genetic manipulation of mouse pancreatic ductal cells. Nat Protoc 8(7):1354-1365. https://doi.org/10. 1038/nprot.2013.079

14. Unno M, Nata K, Noguchi N et al (2002) Production and characterization of Reg knockout mice: reduced proliferation of pancreatic $\beta$-cells in Reg knockout mice. Diabetes 51(Suppl 3):S478-S483. https://doi.org/10.2337/diabetes.51.2007.S478

15. Ota H, Itaya-Hironaka A, Yamauchi A et al (2013) Pancreatic $\beta$ cell proliferation by intermittent hypoxia via up-regulation of Reg family genes and HGF gene. Life Sci 93(18-19):664-672. https://doi. org/10.1016/j.lfs.2013.09.001

16. Liu JL, Cui W, Li B, Lu Y (2008) Possible roles of reg family proteins in pancreatic islet cell growth. Endocr Metab Immune Disord Drug Targets 8(1):1-10. https://doi.org/10.2174/ 187153008783928361

17. Ding S, Blue RE, Morgan DR, Lund PK (2014) Comparison of multiple enzyme activatable near-infrared fluorescent molecular probes for detection and quantification of inflammation in murine colitis models. Inflamm Bowel Dis 20(2):363-377. https://doi.org/ 10.1097/01.MIB.0000440612.98950.79

18. Rogers GJ, Hodgkin MN, Squires PE (2007) E-cadherin and cell adhesion: a role in architecture and function in the pancreatic islet. Cell Physiol Biochem 20(6):987-994. https://doi.org/10.1159/ 000110459

19. Bosco D, Rouiller DG, Halban PA (2007) Differential expression of E-cadherin at the surface of rat $\beta$-cells as a marker of functional heterogeneity. J Endocrinol 194(1):21-29. https://doi.org/10.1677/ JOE-06-0169

20. Torres VA, Tapia JC, Rodriguez DA et al (2007) E-cadherin is required for caveolin-1-mediated down-regulation of the inhibitor of apoptosis protein survivin via reduced $\beta$-catenin-Tcf/Lef-dependent transcription. Mol Cell Biol 27(21):7703-7717. https://doi. org/10.1128/MCB.01991-06

21. Wakae-Takada N, Xuan S, Watanabe K, Meda P, Leibel RL (2013) Molecular basis for the regulation of islet beta cell mass in mice: the role of E-cadherin. Diabetologia 56(4):856-866. https://doi.org/10. 1007/s00125-012-2824-6 
22. Jing D, Kehoe DE, Tzanakakis ES (2010) Expression of Reg family proteins in embryonic stem cells and its modulation by $\mathrm{Wnt} / \beta$ catenin signaling. Stem Cells Dev 19(9):1307-1319. https://doi. org $/ 10.1089 / \mathrm{scd} .2009 .0398$

23. Cavard C, Terris B, Grimber G et al (2006) Overexpression of regenerating islet-derived 1 alpha and 3 alpha genes in human primary liver tumors with $\beta$-catenin mutations. Oncogene 25(4):599608. https://doi.org/10.1038/sj.onc. 1208860

24. Dahl U, Sjodin A, Semb H (1996) Cadherins regulate aggregation of pancreatic $\beta$-cells in vivo. Development 122(9):2895-2902

25. Esni F, Taljedal IB, Perl AK, Cremer H, Christofori G, Semb H (1999) Neural cell adhesion molecule (N-CAM) is required for cell type segregation and normal ultrastructure in pancreatic islets. $\mathrm{J}$ Cell Biol 144(2):325-337. https://doi.org/10.1083/jcb.144.2.325

26. Watanabe T, Yonemura Y, Yonekura H et al (1994) Pancreatic betacell replication and amelioration of surgical diabetes by Reg protein. Proc Natl Acad Sci U S A 91(9):3589-3592. https://doi.org/ 10.1073/pnas.91.9.3589

27. Li Q, Li B, Miao X, Ramgattie C, Gao ZH, Liu JL (2017) Reg2 expression is required for pancreatic islet compensation in response to aging and high-fat diet-induced obesity. Endocrinology 158(6): 1634-1644. https://doi.org/10.1210/en.2016-1551

28. Carvell MJ, Marsh PJ, Persaud SJ, Jones PM (2007) E-cadherin interactions regulate $\beta$-cell proliferation in islet-like structures. Cell Physiol Biochem 20(5):617-626. https://doi.org/10.1159/ 000107545

29. Maretzky T, Reiss K, Ludwig A et al (2005) ADAM10 mediates Ecadherin shedding and regulates epithelial cell-cell adhesion, migration, and beta-catenin translocation. Proc Natl Acad Sci U S A 102(26):9182-9187. https://doi.org/10.1073/pnas.0500918102

30. Maehr R, Mintern JD, Herman AE et al (2005) Cathepsin L is essential for onset of autoimmune diabetes in NOD mice. J Clin Invest 115(10):2934-2943. https://doi.org/10.1172/JCI25485

31. Hsing LC, Kirk EA, McMillen TS et al (2010) Roles for cathepsins $\mathrm{S}, \mathrm{L}$, and $\mathrm{B}$ in insulitis and diabetes in the NOD mouse. $\mathrm{J}$ Autoimmun 34(2):96-104. https://doi.org/10.1016/j.jaut.2009.07. 003

32. Floyel T, Brorsson C, Nielsen LB et al (2014) CTSH regulates betacell function and disease progression in newly diagnosed type 1 diabetes patients. Proc Natl Acad Sci U S A 111(28):1030510310. https://doi.org/10.1073/pnas.1402571111

33. Reiser J, Adair B, Reinheckel T (2010) Specialized roles for cysteine cathepsins in health and disease. J Clin Invest 120(10):34213431. https://doi.org/10.1172/JCI42918

34. Yasothornsrikul S, Greenbaum D, Medzihradszky KF et al (2003) Cathepsin L in secretory vesicles functions as a prohormoneprocessing enzyme for production of the enkephalin peptide neurotransmitter. Proc Natl Acad Sci U S A 100(16):9590-9595. https:// doi.org/10.1073/pnas.1531542100
35. Kuliawat R, Klumperman J, Ludwig T, Arvan P (1997) Differential sorting of lysosomal enzymes out of the regulated secretory pathway in pancreatic $\beta$-cells. J Cell Biol 137(3):595-608. https://doi. org/10.1083/jcb.137.3.595

36. Brix K, Dunkhorst A, Mayer K, Jordans S (2008) Cysteine cathepsins: cellular roadmap to different functions. Biochimie 90(2):194 207. https://doi.org/10.1016/j.biochi.2007.07.024

37. Pislar A, Perisic Nanut M, Kos J (2015) Lysosomal cysteine peptidases - molecules signaling tumor cell death and survival. Semin Cancer Biol 35:168-179. https://doi.org/10.1016/j.semcancer. 2015.08.001

38. Urbich C, Heeschen C, Aicher A et al (2005) Cathepsin L is required for endothelial progenitor cell-induced neovascularization. Nat Med 11(2):206-213. https://doi.org/10.1038/nm1182

39. El Ouaamari A, Dirice E, Gedeon N et al (2016) SerpinB1 promotes pancreatic $\beta$ cell proliferation. Cell Metab 23(1):194-205. https:// doi.org/10.1016/j.cmet.2015.12.001

40. Shellenberger TD, Mazumdar A, Henderson Y et al (2005) Headpin: a serpin with endogenous and exogenous suppression of angiogenesis. Cancer Res 65(24):11501-11509. https://doi.org/ 10.1158/0008-5472.CAN-05-2262

41. Chen H, Gu X, Liu Y et al (2011) PDGF signalling controls agedependent proliferation in pancreatic $\beta$-cells. Nature 478(7369): 349-355. https://doi.org/10.1038/nature10502

42. Xiao X, Gaffar I, Guo P et al (2014) M2 macrophages promote beta-cell proliferation by up-regulation of SMAD7. Proc Natl Acad Sci U S A 111(13):E1211-E1220. https://doi.org/10.1073/ pnas. 1321347111

43. Sharma RB, O’Donnell AC, Stamateris RE et al (2015) Insulin demand regulates beta cell number via the unfolded protein response. J Clin Invest 125(10):3831-3846. https://doi.org/10.1172/ JCI79264

44. Teta M, Long SY, Wartschow LM, Rankin MM, Kushner JA (2005) Very slow turnover of $\beta$-cells in aged adult mice. Diabetes 54(9): 2557-2567. https://doi.org/10.2337/diabetes.54.9.2557

45. Jackson J, Sim RB, Whelan A, Feighery C (1986) An IgG autoantibody which inactivates C1-inhibitor. Nature 323(6090):722-724. https://doi.org/10.1038/323722a0

46. Daha MR, Fearon DT, Austen KF (1976) C3 nephritic factor $(\mathrm{C} 3 \mathrm{NeF})$ : stabilization of fluid phase and cell-bound alternative pathway convertase. J Immunol 116:1-7

47. Campbell-Thompson ML, Kaddis JS, Wasserfall C et al (2016) The influence of type 1 diabetes on pancreatic weight. Diabetologia 59(1):217-221. https://doi.org/10.1007/s00125-015-3752-z

48. Rodriguez-Calvo T, Ekwall O, Amirian N, Zapardiel-Gonzalo J, von Herrath MG (2014) Increased immune cell infiltration of the exocrine pancreas: a possible contribution to the pathogenesis of type 1 diabetes. Diabetes 63(11):3880-3890. https://doi.org/10. 2337/db14-0549 